\section{REFERENCES}

Arrhenius, G., 1963. Pelagic sediments. In Hill, M. N. (Ed.), The Sea: New York (John Wiley), v. 3, p. 692.

Auffret, G. A., Pastouret, L., Chamley, H., and Lanoix, F., 1974. Influence of the prevailing current regime on sedimentation in the Alboran Sea: Deep-Sea Res., v. 21, p. 839 .

Chamley, H., 1971. Recherches sur la sédimentation argileuse en Méditerranée: Sci. géol., Strasbourg, Mém. 35, p. 225.

Chamley H., 1975a. Sédimentation argileuse en mer Tyrrhénienne au Plio-Pléistocène d'après l'étude du forage JOIDES 132: Groupe franç. Arg. Bull., v. 27, p. 97. 1975b. Sédimentation argileuse en mer Ionienne au Plio-Pléistocène d'après l'étude des forages 125 DSDP: Soc. géol. France Bull., v. 17, p. 1131.

Chamley, H. and Millot, G., 1972. Néoformation de montmorillonite à partir de diatomées et de cendres dans les sédiments marins de Santorin (Méditerranée orientale): C. R. Acad. Sci., Paris, v. 274, p. 1132.

Chamley, H., Paquet, H., and Millot, G., 1962. Minéraux argileux de vases méditerranéennes: Serv. Carte géol. Als. Lorr. Bull., v. 15, p. 161.

Cristofolini, R., Di Girolamo, P., and Stanzione, D., 1973. Caratteri genetici e mineralogici di Ialoclastiti dell'Altopiano Ibleo (Sicilia) e dell'isola di Procida (Campania): Rendi conti Soc. Ital. Miner. Petr., v. 29, p. 497.

Emelyanov, E. M., 1972. Principal types of recent bottom sediments in the Mediterranean sea: their mineralogy and geochemistry. In Stanley, D. J. (Ed.), The Mediterranean Sea: Stroudsburg (Dowden, Hutchinson and Ross), p. 355.

Griffin, J. J., Windom, H., and Goldberg, E. D., 1968. The distribution of clay minerals in the World ocean: DeepSea Res., v. 15, p. 433.

Grim, R. E. and Vernet, J.-P., 1961. Etude par diffraction des minéraux argileux de vases méditerranéennes: Schweiz. Miner. Petr. Mitt., v. 41 , p. 65.

Honnorez J., 1967. La palagonitisation. Un aspect du volcanisme sous marin: l'altération du verre basique de Palagonia (Sicile): Thèse Univ. libre Bruxelles, p. 227.

Huang, T. C. and Stanley, D. J., 1972. Western Alboran Sea: sediment dispersal, ponding and reversal of currents. In Stanley, D. J., (Ed.), The Mediterranean Sea; (Dowden, Hutchinson and Ross), Stroudsburg, p. 521.

Keller, J. and Ninkovich, D., 1972. Tephra-Lagen in der Agais: Zeit., Deutsch., Geol. Ges., v. 123, p. 579.
Mélières, F., 1974. Recherches sur la dynamique sédimentaire du golfe de Cadix (Espagne): Thèse Sci. nat., Paris VI, p. 1-235.

Müller, G., 1961. Die rezenten Sedimente im Golf von Neapel. 2 - Mineral Neu- und Um-bildung in den rezenten Sedimenten des Golfes von Neapel: Beitr. Miner. Petr., v. 8, p. 1.

Nesteroff, W. D., Sabatier, G., and Heezen, B. C., 1963. Les minéraux argileux dans les sédiments du bassin occidental de la Méditerranée; Congr. Comm. Intern. Et. Sci. Méditerr. (CIESM), Monaco, v. 17, p. 1005.

Ninkovich, D., and Heezen, B. C., 1965. Santorini tephra. In Whittard, W. F. and Bradshaw, R (Ed.), Submarine geology and geophysics: Colston Pap., v. 17, p. 413.

Norin, E., 1953. Occurence of authigenous illitic mica in the sediments of the central Tyrrhenian sea: Geol. Inst. Univ. Uppsala Bull., v. 34, p. 279.

Pierce, J. W. and Stanley, D. J., 1975. Suspended-sediment concentration and mineralogy in the central and western Mediterranean, and mineralogic comparison with bottom sediment: Mar. Geol., v. 19, p. 15.

Quakernaat, J., 1968. X-ray analyses of clay minerals in some recent fluviatile sediments along the coasts of central Italy: Publ. fysisch-geografisch labo. Univ. Amsterdam, v. 12, p. 1-105.

Robert, C., 1974. Contribution à l'étude de la sédimentation argileuse en Méditerranée orientale: Thèse 3è cycle, AixMarseille II, p. 1-81.

Sartori, R. and Tomadin, L., 1974. Suspended mineral matter in the Northern Ionian Sea: Congr. Comm. intern. Et. Sci. Méditerr. (CIESM), Monaco, abstracts.

Tomadin, L., 1973. Minéraux argileux de vases tyrrhéniennes: Congr. Comm. Intern. Et. sci. Méditerr. (CIESM), Athènes, v. 21, p. 909.

1974a. Les minéraux argileux dans les sédiments actuels de la mer Tyrrhénienne: Groupe franç. Arg. Bull., v. 26 , p. 219.

1974b. Origin and dispersal of clay minerals in the Tyrrhenian Sea: Congr. Comm. Intern. Et. Sci. Méditerr. (CIESM), Monaco, abstracts.

Valette, J. N., 1972a. Etude minéralogique et géochimique des sédiments de mer d'Alboran: résultats préliminaires: C. R. Acad. Sci., Paris, v. 275 , p. 2287.

1972b. Etude sédimentologique et géochimique des dépôts littoraux entourant l'ile Vulcano (Italie). Rôle des fumerolles sous-marines dans les processus de néogenèse: Bur. Rech. Géol. Min. Bull., v. 4, p. 25.

\title{
11.3 TURBIDITES AT SITE 374: THEIR COMPOSITION, PROVENANCE AND PALEOBATHYMETRIC SIGNIFICANCE
}

\author{
Jens Müller, Werner Hieke, and Frank Fabricius, Lehrstuhl für Geologie, Technische Universitä,, \\ München, West Germany
}

\begin{abstract}
Pleistocene sediments cored at Site 374 in the Messina Abyssal Plain contain a number of turbidite deposits. Within these, two kinds of mineralogical associations were recognized. The first is low in carbonate with high amounts of quartz and feldspars, while the
\end{abstract}


other is characterized by high amounts of aragonite and $\mathrm{Mg}$-calcite derived from shallow-water environments. The second association is identical with that of turbidites deposited in the Messina Abyssal Plain in the Holocene. A North-African source area is assumed from present-day circum-Ionian carbonate distribution.

Absence of turbidite layers within Pliocene sediments and the low sedimentation rate during this period indicate that the basin morphology did not allow turbidite deposition before the Pleistocene. This is interpreted as an argument for Plio-Pleistocene subsidence of the Ionian basin.

\section{INTRODUCTION}

Textural and compositional analyses of turbidite sequences may provide clues for the determination of their provenance; their stratigraphic position may help to decipher the paleobathymetric development (and tectonic evolution) of their depositional basins.

In the light of existing controversy as to the paleobathymetry of the Mediterranean area during the Miocene (Ryan, Hsü, et al., 1973; Drooger, 1973), the stratigraphic distribution of turbidites in the PlioQuaternary sediment sequence is of great interest.

Site 374 was drilled in the central part of the present-day Messina Abyssal Plain $\left(35^{\circ} 50.87^{\prime} \mathrm{N}, 18^{\circ}\right.$ $11.78^{\prime} \mathrm{E}$; water depth $4078 \mathrm{~m}$ corrected echo sounding). The thickness of post-Messinian sediments at this site is approximately 360 meters and the Pliocene/ Pleistocene boundary is at a depth of about 300 meters.

Within the extremely short sections cored within the Pleistocene sediments a number of layers with graded bedding and/or laminations were described which could be related to turbiditic sedimentation.

Samples from these sequences were analysed for their texture as well as their faunal and mineralogical composition (Figure 1).

\section{RESULTS AND DISCUSSION}

Within the Pleistocene turbidites recognized so far two kinds of mineralogical associations were found:

1) the first association, found in Core 4, Sections 3 and 4 , is characterized by a comparatively high content of quartz, k-felspar, and plagioclase while calcite and dolomite are less abundant. Total carbonate does not exceed 30 percent within the samples analyzed. Mean size varies between $6.3 \Phi$ and $8.3 \Phi$; the sand content ranges from 8 to 1 percent, silt from 80 to 34 percent, and clay from 64 to 12 percent. The sand fraction consists mainly of benthonic and planktonic foraminifera and less abundant echinoid spines, siliceous sponge spicules in addition to unspecified shell material, mica and quartz.

2) the second association was encountered within Cores 1, in the core catchers of Cores 2 and 4, and in Core 5 , Section 1. Its prominent feature is the presence of the carbonate minerals: aragonite (up to $24 \%$ ) and $\mathrm{Mg}$-calcite (up to $18 \%$ ) along with varying amounts of calcite and dolomite. Total carbonate ranges between 29 and 53 percent. Also frequent are quartz, microcline and albite. The clay fraction is composed of smectite, chlorite, kaolinite, illite, mixed-layers (only subordinate), and in some instances attapulgite. A common, but only minor component is hornblende. Mean size ranges from $5.1 \Phi$ to $9 \Phi$. Sand varies between 0 and 41 percent, silt from 38 to 79 percent, and clay from 8 to 59 percent. The sand fraction is composed of benthic and planktonic foraminifer, pteropods, unspecified biogenic shell fragments, mica, quartz, and heavy minerals; subordinate are echinoid debris, skeletal parts of ophiura and holothurians, siliceous sponge spicules, and fragments of bryozoa.

While the first association does not contain any specific components pointing to a specific source area, the second association clearly indicates provenance from a shallow-water area. This conclusion is mainly based on the occurrence and abundance of the metastable carbonate minerals $\mathrm{Mg}$-calcite and aragonite, which have also been found in Quaternary turbidites of the Messina Abyssal Plain. (Milliman and Müller, 1973; Hieke et al., in preparation).

Presently, areas of extensive carbonate productivity appear to be restricted to the northern African coast as is indicated by the studies of Caulet (1972); Fabricius (personal communication); Stoffers (personal communication); Emelyanov (1972) and Venkatarathnam and Ryan (1971). Also, identical carbonate mineral associations have been reported by Chamley (1971) from the slope off Libya. In constrast, available information on the carbonate sedimentation at the western, northern and northeastern border of the Ionian Sea is only scarce and limited to local areas. Preliminary investigations of Recent shelf sediments off the southern coast of Calabria and Apulia (Rumohr and Müller, in preparation) indicate mainly terrigenous deposits there and $\mathrm{Mg}$-calcite was found only locally and in low concentrations, while aragonite appears to be very rare. From the shelf surrounding Cephalonia (Ionian Islands) Braune (1973) found Mg-calcite enrichments in the near shore areas as well on the deeper shelf (up to $10 \%$ ), while aragonite was detected only in minor concentrations.

If one assumes a similar circum-Ionian pattern of carbonate sedimentation in the past which resulted in a comparable carbonate mineral association, a southern (North-African) source for the Plio-Quaternary turbidites containing large amounts of Mg-calcite and aragonite appears most likely. This is supported by the presence of attapulgite which is abundant in Tertiary soils from the north-african borderlands (Chamley and Millot, 1975). As for the non-carbonate fraction of these turbidites, consisting of quartz, microcline, and albite (and hornblende), one can assume acidic intrusive or effusive source rocks. At present no definite source can be attributed to these minerals; they prob- 

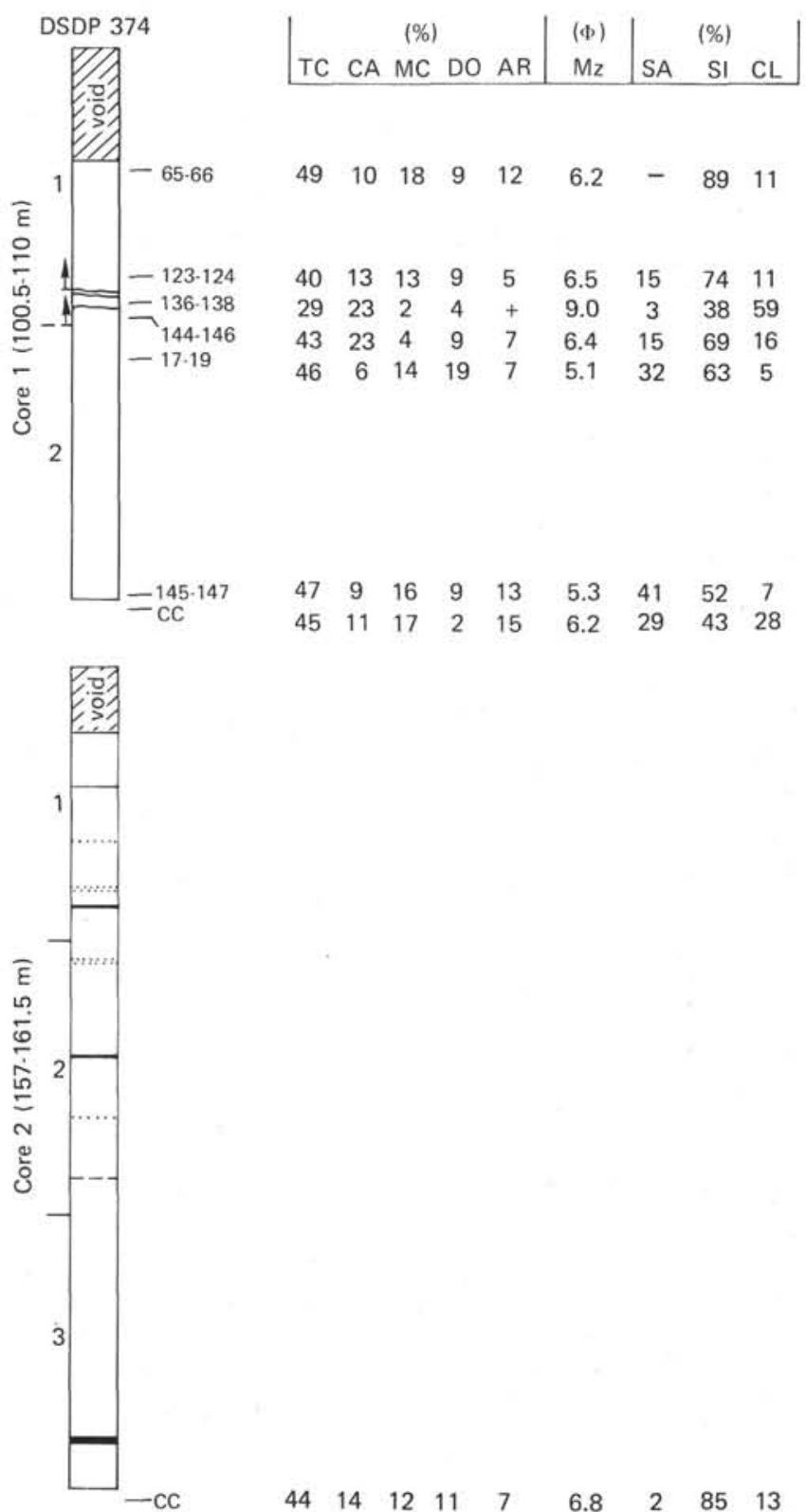

$\begin{array}{lllllllll}44 & 14 & 12 & 11 & 7 & 6.8 & 2 & 85 & 13\end{array}$

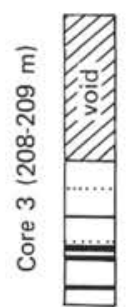

Figure 1. Synopsis of carbonate mineralogy and grain size analyses. Core profile after visual core description (shipboard scientific party). $T C=$ total carbonate, $C A=$ calcite,$M C=M g$-calcite,$D O=$ dolomite,$A R=$ aragonite, $M z=$ mean size (Folk), $S A=$ sand,$S I=$ silt,$C L=$ clay, $c c=$ core catcher .

ably represent an eolian component within the originally shallow-water sediments.

The Pleistocene sedimentation rate at Site 374 was about $15 \mathrm{~cm} / 1000$ years (Cita et al., this volume). On
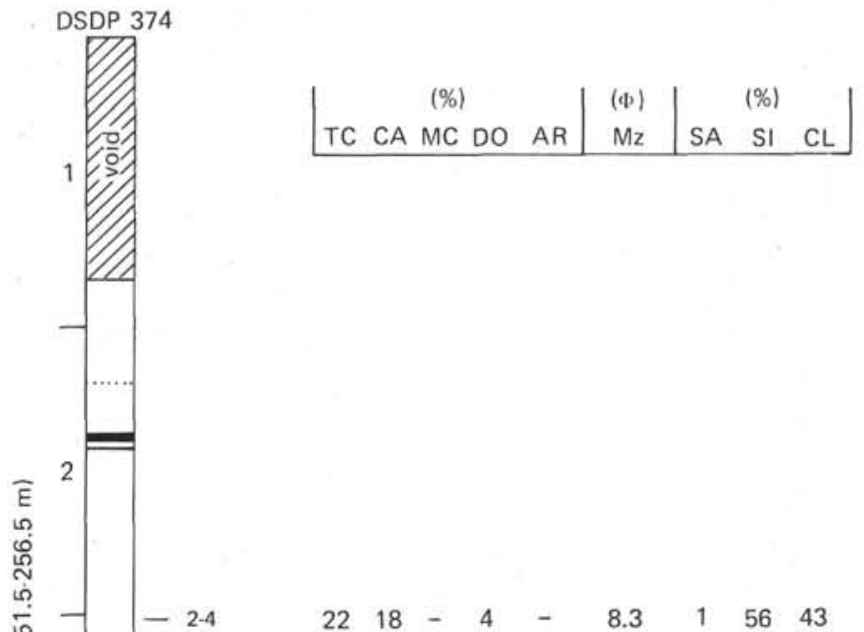

$3127-4 \quad-\quad 6.3 \quad 8 \quad 80 \quad 12$

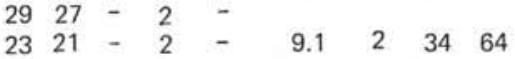

$2119-2-7.0 \quad 1 \quad 73 \quad 26$

$2923-6-$

$\begin{array}{lllll}32 & 21 & 3 & 4 & 4 \\ 34 & 11 & 9 & 8 & 6\end{array}$

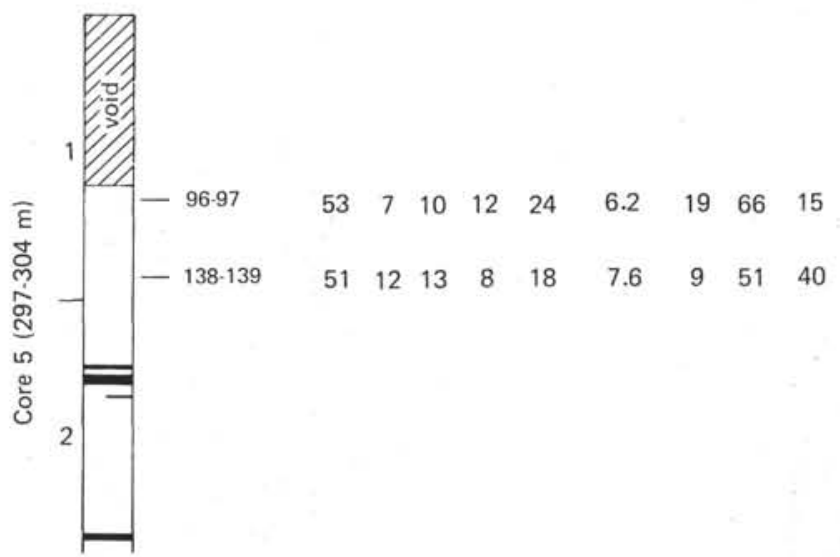

Figure 1. (Continued).

the Mediterranean Ridge, the sedimentation rate calculated for that part of the Pleistocene sequence which can be cored by piston cores (maximum length about $16 \mathrm{~m}$ ) is dependent on differing chronological interpretations of the climatic curves. They vary between 2.4 $\mathrm{cm} / 1000$ years (Cita et al., in press) and about $6 \mathrm{~cm} /$ 1000 years (e.g., Hieke, 1976). In either case, the sedimentation rate at Site 374 is much higher than in the adjacent ridge area. If one assumes that the cored sections of Site 374 are representative of the whole Quaternary sequence, the thickness and occurrence of the clearly recognizable turbidite layers within Cores 1 to 5 are not sufficient to explain the huge sedimenta- 
tion rate. Therefore, one has to expect that many of the "homogeneous" nannofossil marls and oozes of the cored Pleistocene sections of this site are in fact finegrained turbidites. For example, a 12 -meter-thick interval of sediment younger than 9000 years is interpreted as a single turbidite layer and has been found in several piston cores from the Messina Abyssal Plain (Hieke et al., in preparation). This turbidite layer contains about 11 meters of "homogeneous" silty clay.

For the Pliocene sediments at Site 374 which were cored continuously, no indication of turbidite deposition was noted by the shipboard party. Also, no distinct lithologic changes were observed in our X-ray analysis (Müller, this volume). Therefore, it can be concluded, that turbidites played no great role in sedimentation during the Pliocene. This may be supported by the low sedimentation rates as calculated for this interval: 1.3 $\mathrm{cm} / 1000$ years for the lower Pliocene, $5.0 \mathrm{~cm} / 1000$ years for the upper Pliocene (Cita et al., this volume).

\section{CONCLUSIONS}

Site 374 Pliocene sedimentation was more or less free of turbidites which contrasts strongly with a Quaternary turbidite sedimentation. Several factors have been proposed to explain this sharp contrast: (1) changes of the morphology of the Ionian Sea and the surrounding mainland (uplift or subsidence); (2) Quaternary uplift of Calabria (Hsü, personal communication); (3) conditions related to entrapment of sediment following a sudden early Pliocene flooding of a desiccated Mediterranean (Cita et al., this volume).

The "deep-basin desiccation model" assumes a more or less comparable bathymetry to the present one for the Miocene (Ryan, Hsü, et al., 1973) and with respect to this the lack of turbidites in the Pliocene sequence is surprising and difficult to explain. We think, that desiccation of the shallow coast and of parts of the upper slope during the Miocene evaporation periods should produce conditions for weathering and subsequent erosion after the refill of the basin at the beginning of the Pliocene. Cita et al. (this volume) suggest that entrapment of coarse clastic sediments occurred in estuaries after the early Pliocene submergence of the Messinian valleys and therefore there was no transport of material for turbiditic sedimentation on the Messina Abyssal Plain. We are neither aware of the presence of these postulated Messinian valleys within the circum-Ionian area nor have relicts of Pliocene estuaries been found to our knowledge, where such entrapment of coarse sediment material could have occurred. Also, the predominant type of mineral association present within the Pleistocene turbidites did not come from Pliocene estuarine environments nor represents land-derived clastic material but rather came from shallow shelfs or platforms with prevailing biogenic carbonate production.

Finally, the uplift of Calabria and/or Sicily since the Plio-Pleistocene boundary is not responsible for the onset of the dominant carbonate turbidite sedimenta- tion in the Messina Abyssal Plain, since the Pliocene sediments of these areas do not contain carbonate mineral associations such as found in the turbidites.

Therefore, the observed change in the sedimentation regime appears more compatible with the assumption of a "shallow-basin" during the Miocene. We believe that more or less continuous subsidence of the Ionian basin (and concomittant uplift of adjacent areas) finally led to the present-day basin configuration. Apparently only near the Plio/Pleistocene boundary was the necessary morphology existent in the Messina Abyssal Plain for the onset of turbidite deposition.

\section{ACKNOWLEDGMENTS}

This investigation is a part of the sedimentological survey of DSDP material financed by the Deutsche Forschungsgemeinschaft. We thank our colleagues Drs. K. Braune and W. Sigl for discussions and Dr. R. B. Kidd for a critical review of the manuscript.

\section{REFERENCES}

Braune, K., 1973. Die rezenten und pleistozänen Sedimente des Sublitorals von Kephallinia (Ionische Inseln): Senckenbergiana marittima, v. 5, p. 99-133.

Caulet, J., 1972. Les sédiments organogènes du précontinent algérien: Mém. Museum National d'Histoire Naturelle, Nouv. Sér., C, v. XXV, p 289.

Chamley, H., 1971. Recherches sur la sédimentation argileuse en Méditerranée: Thèse Université Marseille, p. 401.

Chamley, H. and Millot, G., 1975. Observations sur la répartition et la genèse des attapulgites plio-quaternaires de Méditerranée: C. R. Acad. Sci., Paris, Sér. D, v. 81, p. 1215-1218.

Cita, M., Vergnaud-Grazzini, C., Robert C. Chamley, H. Ciaranfi, N., and d'Onofrio, S., in press. Paleoclimatic record of a long deep-sea core from the eastern Mediterranean: Quaternary Research.

Drooger, C., (Ed), 1973. Messinian events in the Mediterranean. Geodynamics Scientific Report No. 7 on the colloquim held in Utrecht, March 2-4, 1973: North-Holland Publishing Company, p 272.

Emelyanov, E., 1972. Principal types of recent bottom sediments in the Mediterranean Sea: their mineralogy and geochemistry. In Stanley, D. J. (Ed.), The Mediterranean Sea: Dowden, Hutchinson \& Ross, p. 355-386.

Hieke, W., 1976. Problems of eastern Mediterranean late Quaternary stratigraphy - a critical evaluation of literature: Meteor Forschungs-Ergebnisse, v. 24, p. 68-88.

Hieke, W., Melguen, M., and Fabricius, F., in preparation. Turbidites from the Messina Abyssal Plain and the Mediterranean Ridge - possible indications of young tectonics.

Milliman, J. and Müller, J., 1973. Precipitation and lithification of magnesian calcite in the deep-sea sediments of the eastern Mediterranean Sea: Sedimentology, v. 20, p. 2945.

Ryan, W. B. F., Hsü, K. J., et al., 1973. Initial reports of the Deep Sea Drilling Project, Volume 13: Washington (U.S. Government Printing Office).

Venkatarathnam, K. and Ryan, W. B. F., 1971. Dispersal patterns of clay minerals in the sediments of the eastern Mediterranean Sea: Marine Geology, v. 11, p. 261-282. 